\title{
The Sub-Center Construction of the China's Great Bay Area-Take Nansha as an Example
}

\author{
Yue You \\ Land Resource Management, Academy of Public Administration, Jinan University, Guangzhou, China \\ Email: 2453752111@qq.com
}

How to cite this paper: You, Y. (2017). The Sub-Center Construction of the China's Great Bay Area-Take Nansha as an Example. Chinese Studies, 6, 181-187. https://doi.org/10.4236/chnstd.2017.63018

Received: July 7, 2017

Accepted: July 25, 2017

Published: July 28, 2017

Copyright $\odot 2017$ by author and Scientific Research Publishing Inc.

This work is licensed under the Creative

Commons Attribution International

License (CC BY 4.0).

http://creativecommons.org/licenses/by/4.0/

\begin{abstract}
The organic evacuation of a city forms a new pattern of structure to guide the asserts flow as well as cash flow efficiently in order to (delete) push the development of cities to a qualitative level. During the transformation of large-scale city, problems such as population explosion, traffic jams, the lower quality of life, are faced by the modern city. To build a new district has been a popular way to solve the problem. A new district that arms with certain scale should be built to obey the trend. The new district should combine its land strength to develop innovative industry to build its own diverse functions; the new district should be located in the key area of a city and keep certain connection with the main area. The article studies the strategy of Nansha's, building the city sub-center through comparison and literature research, providing a new model of how to build city sub-center.
\end{abstract}

\section{Keywords}

Sub-Center, Population, China’s Great Bay Area, Comparison, Nansha

\section{Introduction}

In 2016, the Nansha city sub-center construction has been come up with. At the same time, Beijing Tongzhou also put forward the similar plan. As the two firsttier cities put forward the city sub-city successively, the innovative way of city planning should be worth considering. The article takes Nansha as an example to inform us the constructing experience.

\section{The Developmental Pattern of Sub-Center and International Comparison}

The foreign academic research of Sub-center focus on the theory of city space and the reason why Sub-center could be formed, make less consideration towards the government and industry that strengthen the function (Zhang Kailin, 
2005). Since the 1950s and 1960s, though the way of building the city sub-center, some considerations come out one by one in large cities such as New York, Paris, Tokyo and so on.

\section{Cases-Sub-Center of Beijing and Tokyo}

As China defined as the second economy, the population of Guangzhou has reached 16 million, Guangzhou become a comprehensive diversified metropolis as the key city of China. How to stand in line with advanced cities? Using the existing reference can reduce the risk of crossing the river by touching stone. For relatively single function, whose scale at millions like Singapore, Hong Kong can only be set as models. We should compare with comprehensive multiscale cities like New York, London, Tokyo, Paris, Beijing. As Tokyo stands for the eastern Asia, we can see it as the foreign city for standard.

\subsection{The City Planning of Beijing Tongzhou}

The reason why this article take case of Tongzhou is that there exists much similar between Tongzhou and Nansha: for geographic condition, rich water port resources, convenient traffic condition, nearby the center city; for natural resources, gathering water networks, take obvious advantage on natural ecology; for tourism resources (Zhao Hong, 2009), both are kept intact no matter natural or cultural; for planning, Tongzhou aims at building as the of outstanding loading area of worldwide city as well as a new magnetic pole of Beijing; Nansha defined as the comprehensive test area of China's great bay area's comprehensive cooperation, the new hub of word-class pearl river delta urban agglomeration, the key center of Guangzhou, it is appropriate to compare with Tongzhou (Lin Xueda, 2012).

The progress of the building of Beijing Tongzhou city sub-center conforms us that: the Nansha new district should be comprehensively defined for the reason that only diversified function can gather popularity, forming some radiational and driving effects on surrounding area (Wang Chengrong, Han Ningchun, \& Kang Jian, 2014); the relocation of the administrative center is a effective push to the new district; new constructive concept like Ecological city, Wisdom city, Sponge city could be more easily taken into implementation (Ma Yaxi, 2010).

\subsection{Shinjuku, Tokyo}

Japan contains lots of city sub-center which can be divided into the comprehensive style and functional that are full of characters and worth taking for example (Wu Linjie \& Qu tao, 2012). The city sub-center in Japan can be divided into comprehensive style and function dominated style while the later one occupies less. During 30 year's construction, On the one hand, gathering high-quality business group through utilizing the business-office function; on the other hand, gathering popularity of the business effect to avoid the gap of CBD between day and night, finally even being an empty city.

The planning of city sub-center of Shinjuku informs us that it's efficient to 
gather population by adopting the method of building for the hub of urbanrailway system (Ma Haitao, Luo Kui, Sun Wei et al., 2014); the Nansha new district needs to make overall efforts to develop the third industry from both sides containing aspects like productive and livable, living first, working second. The moving in of administration and colleges is an effective method to promote the development of the new district; constructing traditional commercial or develop street cultural entertainment is a kind of effective way to gather popularity.

\section{Advantages and Disadvantages: From Demographic and Industrial Perspectives}

\subsection{From Population Density Angle: There Exists Large Population Growth Space in Nansha New District}

Beijing Tongzhou and Guangzhou Nansha put forward the project of construction of city sub-center in 2016 successively. By comparing the Population indicator data of the two regions in 2010 and 2014, the registered population density of Tongzhou was 2.51 times and 1.62 times the registered population density of Nansha new area. The fact that Nansha shows a smaller density base reflects that it has restored a potential space to grow. The population growth rate of Nansha grows rapidly on account of the join in of the three towns in north, which is far more higher than that of Tongzhou. The permanent resident population density was 2.65 times and 1.85 times the permanent resident population density of Nansha new area. On the other side, the growth rate of Nansha.

From 2010 to 2014, the percent of Beijing tongzhou's registered population accounts for the proportion of permanent resident population had declined $4.01 \%$, the index of Nansha new area basically remains unchanged, just range from $59.25 \%$ to $59.41 \%$ (Table 1). For the reason that external population is the main source of population growth which informs that the degree of difficulty to register one's residence in Beijing makes it difficult for external population to get registered in Beijing, so decline the percent of registered population accounts for the proportion of permanent resident population. The change of the percent of registered population accounts for the proportion of permanent resident population reflects that the registered system of Guangzhou is not that hard as Beijing (Mi Ruihua \& Shi Ying, 2014). As the fact that the future industry of Nansha mainly aims to attract the well-educated population. If conditions to make them easilier to register, the percent of registered population accounts for the proportion of permanent resident population of Nansha would be increased.

\subsection{From the Perspective of Population Structure: "Umbrella" Structure, the Aging Progress Is Speeding.}

The sixth census shows that, the structure of permanent resident population in 2010 is like "umbrella"-structure which mainly takes out as the proportion of youth is on the lower side while the proportion of labor and the old is on the higher side.

According to Table 2, the outstanding 15 - 64 year old group shows the rich 
Table 1. Comparison of population indicators in the three districts of Beijing tongzhou and Guangzhou Nansha.

\begin{tabular}{|c|c|c|c|c|c|c|}
\hline & \multicolumn{3}{|c|}{ Beijing Tongzhou } & \multicolumn{3}{|c|}{ Nansha } \\
\hline & 2010 & 2014 & $\begin{array}{l}\text { Growth } \\
\text { rate\% }\end{array}$ & 2010 & 2014 & $\begin{array}{l}\text { Growth } \\
\text { rate\% }\end{array}$ \\
\hline $\begin{array}{l}\text { Registered population } \\
\text { (ten thousand people) }\end{array}$ & 66.3 & 70.5 & 5.96 & 15.41 & 37.74 & 59.17 \\
\hline $\begin{array}{l}\text { Registered Population density } \\
\text { (man/square kilometer) }\end{array}$ & 732 & 778 & 5.91 & 292 & 481 & 39.29 \\
\hline $\begin{array}{l}\text { Permanent resident population } \\
\text { (ten thousand people) }\end{array}$ & 118.4 & 135.6 & 12.68 & 26.01 & 63.53 & 57.26 \\
\hline $\begin{array}{c}\text { Permanent resident } \\
\text { population density } \\
\text { (man/square kilometer) }\end{array}$ & 1307 & 1496 & 12.63 & 493 & 810 & 39.14 \\
\hline $\begin{array}{c}\text { Proportion } \\
\text { (registered/permanent\%) }\end{array}$ & 56 & 51.99 & -4.01 & 59.25 & 59.41 & 0.16 \\
\hline
\end{tabular}

Data resource: Beijing statistical yearbook, Guangzhou statistical yearbook.

Table 2. The sixth census and $1 \%$ sample survey about comparison in age structure of Nansha new area.

\begin{tabular}{ccccc}
\hline \multirow{2}{*}{ Age group } & \multicolumn{2}{c}{ Population (ten thousand people) } & \multicolumn{2}{c}{ Percent (\%) } \\
\cline { 2 - 5 } & In 2010 & In 2015 & In 2010 & In 2015 \\
\hline 0 - 14 years old & 3.12 & 0.27 & 12.02 & 11.14 \\
15 - 64 years old & 21.35 & 2.02 & 82.16 & 81.46 \\
Age 65 and older & 1.51 & 0.18 & 5.82 & 7.39 \\
\hline
\end{tabular}

Data resource: The sixth census and $1 \%$ sample survey.

labor resource of Nansha. Comparing to 2010, it only reduces $0.7 \%$ which shows the group is the main population of Nansha. According to the national standard of aging group which is defined as $7 \%$ of the age 65 and older, Nansha is stepping into the aging society which informs us that the labor level should be improved to reduce structural unemployment to push the improvement of Nansha to release the aging pressure.

On population side, there exists certain problems. First of all, the character of population side: the population size is smaller and being increasing at a high speed, the natural rising speed of registered population is low while the rising speed of permanent resident population is fast; secondly, he character of the cultural quality of population: the high-educated person is on the top of the pyramid while the possession is too low; thirdly, the character of population structure: the aging trend is around the corner, the possession of youth labor is high, the total dependency ratio is low, the labor resource is rich; fourthly, the character of population distribution: mainly focusing in the second industry, the labor shows out the character of inefficient of the "second-third-first" (Huang Cangfu \& Hu Yurong, 2012). If new labor resource is not allowed in, the possession of 
future labor resource would decline, the demographic dividend would disappear. So it's necessary to introduce in excellent capital and a large amount of welleducated labor resource through the way of making full use of the innovative industry, adding extra value to the labor in order to keep the advantage of demographic dividend.

\subsection{The Matching of Population Function}

At present, the so called linear relationship exists between the population growth and economic growth while the inner space is different. The distribution of population and economy of certain area is not perfectly matched, so does the speed of the rising of population and the development of economy which must leading the result of the outstanding population pressure and the developing gap in the area of the inner city. It matches well between the population structure and industry structure and the employing structure possesses similarly with industry-production structure. But there is still a large improving space in labor productivity and industrial structure performance. It is a trend to transform the labor from the first industry and the second industry to the third industry. The degree of population and city distribution is also high and it's not matched in population distribution according to the original planning as its more crowded in north. Facing the increasing population, it's on the schedule for the government to take positive steps in investing heavier in public service and facilities to improve the convenience of the citizen life and enhance the happiness index of living in the city.

\section{The Sub-Center Construction of the China's Great Bay Area}

Under the background of the excellent resource is gathered in China's great bay area, it is important to strength then the inner innovative ability of Nansha. We should motivate the "green card" which can be used to make full enjoy of "Chinese national treatment" and "citizen treatment"; by establishing a public service based on service facilities and efficiency, taking the initiative to talented people from Hong Kong and Macao. To attract advanced and high-quality producing industry in the international industry, including accounting, finance, advertising, law and management consulting; the idea of hanging up is to expend the exchanges to hang up outside to promote the recognition of Nansha which is a practical way to provide the management service. Switzerland is an innovative country with outstanding International community, to host the project with Switzerland is productive to strengthen the links Between the Nansha free trade area and developed economies.

\section{The Strategy to Construct the Nansha City Sub-Center}

Nansha will be the center of the secondary center of Guangzhou and the central axis of the city; the central axis can be based on the hat peak mountains, the pearl bay area block and Qingsheng block as the main body. To optimize the 
function of the Nansha shipping hub, the comprehensive traffic block and Qingsheng block come first. Nansha port is the leading role when we talking Nansha in the international shipping lanes. The docking of port facilities and service facilities in the hinterland will effectively promote the development of Nansha port.

\section{Conclusion and Discussion}

Under the background of global economy, a cost-index containing the financial cost, time cost, risk cost becomes a key index in measuring the whole competing quality, and it is of great significance for Nansha to improve its own competitive ability by taking strict measures in constructing and the operating cost of enterprises. The excellent, standard, efficient global service sets aside space for the allocation and application of resource.

As a conclusion, we can learn from the construction of Nansha's city subcenter that we should keep certain relationship with the main city area, making full use of the advantage of policy and the location. As Nansha neighboring Macao and Hongkong, it's of great advantage to introduce in excellent resource. Introducing well-educated population which can be a lasting motivation to the development to the sub-center is also important in sub-center constructing.

\section{References}

Huang Cangfu, \& Hu Yurong. 黄昌富, 胡玉蓉. (2012). Interregional Contact Angle of Provincial Deputy Center City Industry Positioning Study 区际联系视角的省域副中 心城市产业定位研究. Journal of Three Gorges University, Humanities and Social Science Edition, 34, 71-74.

Lin Xueda. 林学达. (2012). Tongzhou-Vice Center Capital Connotation, Orientation and Construction Pattern 通州一首都副中心的内涵, 定位与建设格局. Journal of Urban and Rural Construction, 11, 013.

Ma Haitao, Luo Kui, Sun Wei et al. 马海涛, 罗奎, 孙威, 等. (2014). Deputy City Center of Tokyo Shinjuku Construction Experience and Enlightenment 东京新宿建设城市副 中心的经验与启示. Journal of World Geography Research, 1, 103-110.

Ma Yaxi. 马亚西. (2010). Tokyo and Paris Building Construction Vice Center of Beijing City World Cities Provide Reference 巴黎打造城市副中心为北京建设世界城市提供 的借鉴. Journal of Planning and Construction in Beijing, No. 6, 46-47.

Mi Ruihua, \& Shi Ying. 米瑞华, 石英. (2014). Based on the Distribution of the Population of Permanent Residents in the City the Main Deputy Center Recognition Method 基于常住人口分布的城市主副中心识别方法. Journal of Shaanxi Normal University (Natural Science Edition), 42, No. 3.

Wang Chengrong, Han Ningchun, \& Kang Jian. 王成荣, 韩凝春, 康健. (2014). Deputy City Center of Beijing Tongzhou District Development Emerging City CBD Thinking 关于北京城市副中心通州区发展城市新兴 CBD 的思考. Journal of Commercial Age, 135-138.

Wu Linjie, \& Qu tao 吴聆捷, 渠滔. (2012). Comparison between China and Japan Deputy Center City Regional Development Pattern 中国与日本城市副中心区位发展模式 之比较. Journal of China City, No. 12, 43-47.

Zhang Kailin. 张开琳. (2005). Deputy Center City Construction 大城市副中心建设理 
论与实践. Journal of Theory and Practice of Urban Problems, No. 2, 73-76.

Zhao Hong. 赵弘. (2009). Vice Center of Beijing Urban Construction 论北京城市副中 心建设. Journal of Urban Problems, No. 5, 36-40.

Submit or recommend next manuscript to SCIRP and we will provide best service for you:

Accepting pre-submission inquiries through Email, Facebook, LinkedIn, Twitter, etc. A wide selection of journals (inclusive of 9 subjects, more than 200 journals)

Providing 24-hour high-quality service

User-friendly online submission system

Fair and swift peer-review system

Efficient typesetting and proofreading procedure

Display of the result of downloads and visits, as well as the number of cited articles Maximum dissemination of your research work

Submit your manuscript at: http://papersubmission.scirp.org/

Or contact chnstd@scirp.org 